\title{
Reseña de María Fernández López (Marcia Belisarda), Obra poética completa, ed. Martina Vinatea Recoba, New York, IDEA, 2015, 483 pp. ISBN: 978-1-938795-03-91
}

\section{Davinia Rodríguez Ortega}

Universidad Pública de Navarra ESPAÑA

davinia.rodriguez@unavarra.es

[Hipogrifo, (issn: 2328-1308), 3.2, 2015, pp. 297-300]

Recibido: 16-09-2015 / Aceptado: 03-10-2015

DOI: http://dx.doi.org/10.13035/H.2015.03.02.20

El presente volumen ofrece al lector el texto anotado de la Obra literaria completa compuesta por la religiosa toledana María Fernández López, quien firmó sus escritos bajo el seudónimo de Marcia Belisarda, junto con una rigurosa y ajustada introducción a la poesía de la monja. La investigadora responsable de llevar a buen puerto tan loable proyecto es Martina Vinatea, conocedora del quehacer literario femenino durante el Siglo de Oro, según ya demostró con trabajos anteriores como la edición crítica de la Epístola de Amarilis a Belardo².

Dentro del amplísimo panorama literario que ofrece el Siglo de Oro español, tradicionalmente apenas se ha estudiado la parcela perteneciente a la producción literaria de los conventos, de autoría en esencia femenina. De este modo, se constataba la grandeza del periodo a través de las plumas de grandes autores como Calderón, Lope de Vega o Tirso de Molina, pero presentando la realidad del siglo XVII de un modo sesgado, puesto que se estaba obviando la vasta presencia de la literatura en los conventos españoles. La gran mayoría de obras compuestas por monjas se refieren a «vidas»: semblanzas biográficas en ocasiones propias, pero en la mayoría de los casos en torno a la figura de compañeras. No obstante, este tipo de producción escrita de carácter más ejemplarizante y didáctico se combina con textos de esencia poética e incluso piezas teatrales para ser representadas dentro del recinto de la congregación por las propias religiosas. Como consecuencia, es-

1. Este trabajo académico se ha llevado a cabo gracias a una ayuda postdoctoral de la Universidad Pública de Navarra.

2. Martina Vinatea Recoba (ed.), Epístola de Amarilis a Belardo, Pamplona/Madrid, Universidad de Navarra/Iberoamericana/Vervuert, 2009, Biblioteca Indiana 15. 
tas autoras encuentraban un espacio entre sus oraciones para el deleite artístico mediante las letras, que se suponen escritas para el entretenimiento común de las monjas, para celebrar festividades específicas o participar en justas poéticas, etc. y se intercambiaban los textos entre las diversas órdenes conventuales. Por el contrario, en ocasiones, aunque escasas, también tendrían en mente la publicación de las mismas, como bien ejemplifica este manuscrito, con prólogo y poemas encomiásticos introductorios, junto con la producción poética, lo que nos induce a pensar que estaba copiado para ser llevado a la imprenta, si bien finalmente ha llegado al lector de nuestros días por cauces distintos. También, ese deseo de difusión deja traslucir la intención de Marcia Belisarda de darse a conocer como escritora dentro de su entorno, traspasando los muros del convento.

En el caso particular de la poesía de Marcia Belisarda, el manuscrito que contiene su obra se encuentra en la Biblioteca Nacional de España, aunque la fecha de incorporación al catálogo es incierta. Sí deduce la autora, que si se encuentra entre los fondos públicos de dicha institución y no en el convento toledano donde fue compuesta, es posiblemente porque fuera expropiado durante la desamortización de los bienes de la Iglesia impulsada por Mendizábal entre 1836-1837. Tampoco es posible indicar con exactitud la fecha de composición del manuscrito, si bien pertenece al siglo XVII, según indica el tipo de letra utilizada y las referencias incluidas en varios de sus poemas. El lapso de tiempo que ofrece la investigadora abarca desde 1642 a 1646, por lo que el testimonio pudo ser compuesto a lo largo de esta década.

La obra, con signatura Ms. 7469, consta de 88 folios escritos por siete manos diferentes: seis de ellos aparecen únicamente copiando los poemas encomiásticos ubicados al comienzo del volumen, mientras que el resto de la producción poética es fruto de un solo amanuense, la monja Marcia Belisarda. Con gran acierto, Vinatea dedica varias páginas a detallar las incursiones de cada copista dentro del manuscrito, ejemplificado la caligrafía particular de cada uno de ellos mediante imágenes; como consecuencia, el lector puede comprobar visualmente la teoría expuesta y se pone de manifiesto la cuidada investigación llevada a cabo por la editora del volumen.

Marcia Belisarda, autora de la obra poética aquí estudiada, era una religiosa toledana del XVII, por ello se incluye en el estudio preliminar un espacio dedicado a analizar la situación del Toledo contemporáneo y el escenario literario femenino, compilando una nómina de autoras que escribieron al tiempo de nuestra poeta. La editora resalta cómo Toledo se convirtió, desde el traslado de la corte de Felipe II a Madrid, en una ciudad de marcada presencia espiritual, plagada de conventos y monasterios, abandonando la importancia política que había tenido años antes, lo que conlleva asimismo el comienzo de la decadencia económica. Sin embargo, la ciudad-convento destacaba por una fuerte presencia de la literatura, y en especial de la poesía: los escritos se dedicaban en gran parte a temas católicos, a la hagiografía, la figura de Cristo, etc. y se producían dentro de los muros conventuales.

La ciudad castellana ya contaba con una importante tradición poética desde el Renacimiento con Garcilaso de la Vega y hasta la época de Marcia Belisarda con 
Lope de Vega. Asimismo, la celebración de justas poéticas, certámenes y academias, tan del gusto aurisecular, no hacía sino potenciar toda la inspiración latente en la religiosa y también cultural Toledo. Asimismo, hay otro acontecimiento que nos ayuda a explicar cómo es posible que una mujer religiosa decida tomar la pluma: la carmelita Teresa de Jesús supuso un modelo no solo de vida sino de actuación, y desde entonces muchas monjas se aplicaron con entusiasmo a la escritura. Como ejemplo del gran número de autoras religiosas toledanas coetáneas al poemario de Marcia Belisarda (1630-1670), la editora propone un análisis detallados de hasta catorce monjas pertenecientes a distintos conventos: Juana de Bayllo, sor Estefanía de Ocaña, sor Catalina de Cristo, sor Catalina de san Antonio, etc. aunque es consciente de la multitud de autoras desconocidas y la necesidad de investigar en los archivos custodiados por estas congregaciones.

A continuación, Vinatea nos dibuja una semblanza de la vida de Marcia Belisarda, apoyada en la obra de Manuel Serrano y Sanz, Apuntes para una biblioteca de autoras españolas desde el año 1401 al 1833, que además de complemento bibliográfico le sirve para refutar la afirmación por él formulada, y después seguida por la crítica, de la pertenencia de la monja al convento de las concepcionistas. Por el contrario, la editora del volumen considera que «no existe razón alguna de peso para adscribir a Marcia Belisarda a alguna congregación» (p. 55), porque del mismo modo que dedica poemas a santa Beatriz de Silva, monja de la Concepción francisca, también escribe múltiples de ellos para Santiago, patrón de España y de las Comendadoras de Santiago. Las pesquisas archivísticas de la investigadora le llevaron a encontrar el expediente de limpieza de sangre de Marcia Belisarda y una vida de monja escrita por María de Santa Isabel (nombre original de nuestra poeta): Vida de la venerable madre María Bautista (coincidiendo en amanuense con la Obra poética que aquí se edita); por tanto, la hipótesis que establece Vinatea posee mayor rigor científico que la tradicional, de manera que es posible imaginar a la religiosa formando parte de las Comendadoras de Toledo, en el convento de la Santa Fe.

El orden de los poemas en la edición crítica ha respetado la disposición inicial del manuscrito, porque, aunque existen multitud de referencias temporales, sería imposible establecer el orden cronológico exacto de su composición. No obstante, no sería desacertado pensar que Marcia Belisarda ya siguió ese criterio de ordenación puesto que el primero de ellos tiene el subtítulo de «Romance que fue el primero que escribí a los 27 años de mi edad» (p. 133). Pero en este aspecto concreto nos movemos en el estricto terreno de las suposiciones. Teniendo en cuenta criterios de funcionalidad, la obra poética puede ser dividida en: poemas para ser leídos (65) y para ser cantados (83); según su carácter, son de contenido religioso (101) o profano (47). En el volumen editado se presentan estas cifras en diagramas para una mejor comprensión. Finalmente, Vinatea concluye la introducción con un exhaustivo estudio de las formas métricas y motivos utilizados por la religiosa en su producción poética.

El siguiente apartado, la obra completa de Marcia Belisarda, es el más extenso del presente volumen, como es de esperar. Cada poema es analizado siguiendo una misma estructura: comentario, forma estrófica y anotación; esta última cubre 
aspectos de diversa índole como aclaración de significado, referencias bíblicas o poéticas, alusiones a obras de autores clásicos, etc. todo ello muy bien nivelado, lo que permite una lectura profunda a la vez que fluida de los sucesivos poemas. También, como en el caso de la ejemplificación de las diferentes manos mediante imágenes, los poemas, cada vez que la ocasión lo requiere, vienen acompañados de las referencias visuales que han servido de inspiración o establecen un juego interartístico con los poemas de la monja toledana. Todo este trabajo de documentación por parte de la investigadora Vinatea, redunda en una edición lo más completa posible, haciendo buen uso de los medios de reproducción actuales, para ofrecer al lector el texto definitivo de los poemas de Marcia Belisarda.

Respecto a las grafías y la puntuación, en ambos casos se ha adaptado a los usos actuales, así como la acentuación, excepto en ejemplos significativos. En cuanto a los criterios de edición, se han seguido los propuestos por GRISO, que tan eficaces han resultado a lo largo de sus numerosas publicaciones críticas. Las partes omitidas en el manuscrito y las erratas detectadas se han tratado de subsanar, siempre indicando en nota las intervenciones por parte de Vinatea.

Las últimas páginas se dedican a transcribir los dos documentos que sostienen la hipótesis de la pertenencia de Marcia Belisarda al convento de las Comendadoras de Santiago, con un ejemplo de la escritura de la Vida de la Venerable Madre María Bautista, para que pueda ser comparado con el principal amanuense del manuscrito aquí editado.

No obstante, además de ensalzar la cuidada y metódica labor editorial de la investigadora Martina Vinatea, es posible mencionar un apartado que echamos a faltar en el volumen: la inclusión de un índice de notas final, que evitaría la reiteración de algunas voces a lo largo del poemario de Marcia Belisarda. Pero este detalle no desmerece en modo alguno el magno trabajo aquí reunido que contribuye, como un pilar esencial, a la reciente pero fructífera investigación que se está realizando en torno a la literatura conventual femenina del Siglo de Oro. 